\title{
Kedudukan Asas Hukum dalam Penyelesaian Sengketa Melalui Arbitrase Berdasarkan Undang-Undang Nomor 30 Tahun 1999
}

\author{
Supeno $^{1}$, Muhtar Dahri ${ }^{2}$, Hafid Zakariya ${ }^{3}$ \\ Fakultas Hukum Universitas Batanghari Jalan Slamet Riyadi Broni Kota Jambi Telp: (0741) 65351 \\ msasyabani@gmail.com, mukhtardahri76@gmail.com, hafidzakariya@gmail.com
}

\begin{abstract}
Abstrak. Ditetapkannya Undang-Undang Nomor 30 Tahun 1999 Tentang Arbitrase dan Alternatif Penyelesaian Sengketa merupakan langkah maju dalam penyelesaian sengketa di Indonesia terutama penyelesaian sengketa di bidang perdagangan sebagai jawaban atas kebuntuan dalam penylesaian sengketa perdagangan yang membutuhkan penyelesaian secara cepat, murah, informal, dan terjaga kepentingan dan rahasia para pihak. Akan tetapi masih terdapat beberapa aturan dan praktik yang tidak sejalan dengan asas hukum arbitrase itu sendiri. Dalam tulisan ini akan dikaji dan dianalisis kedudukan asas hukum yang digunakan dalam penyelesaian sengketa melalui arbitrase dengan demikian diharapkan asas-asas hukum ini dapat dijunjung tinggi oleh semua pihak yang berkepentingan, jika ada aturan hukum dan praktik hukum yang bertentangan dengan asas hukum ini dapat dikesampingkan.
\end{abstract}

Kata kunci: asas hukum, arbitrase

Abstract. The enactment of Law No. 30 of 1999 concerning Arbitration and Alternative Dispute Resolution is a step forward in dispute resolution in Indonesia, especially the settlement of disputes in the field of trade in response to the deadlock in the settlement of trade disputes that require resolutions quickly, cheaply, informally, and maintained interests and the secrets of the parties. However, there are still some rules and practices that are not in line with the principle of arbitration law itself. In this paper will be reviewed and analyzed the position of the legal principle used in resolving disputes through arbitration, so it is hoped that these legal principles can be upheld by all interested parties, if there are legal rules and legal practices that are contrary to this legal principle, they can be ruled out.

Keywords: legal principle, arbitration

\section{PENDAHULUAN}

Kedudukan asas hukum dalam suatu peraturan perundang-undangan memiliki kedudukan yang sangat penting dan strategis karena sejatinya kedudukan asas hukum lebih tinggi dibandingkan dengan norma hokum itu sendiri, dalam literature hokum modern terdapat beberapa asas hokum yang memiliki keberlakuan yang bersifat universal terutama bagi negara-negara yang menganut civil law system, yaitu:

Menurut Kamus Besar Bahasa Indonesia (KBBI), pengertian "asas" memiliki tiga makna yaitu:

1. Asas lex posterior derogate legi priori (peraturan yang baru akan menghapus peraturan yang lama);

Asas ini menegaskan bahwa dengan diundangkannya suatu peraturan perundang-undangan yang baru sebagai hasil amandemen atau perubahan maka ketentuan yang lama dengan sendirinya tidak berlaku lagi sebagai undang-undang, sebagai contoh dengan telah diamandemennya beberapa pasal yang ada dalam Undang-Undang Dasar 1945 pada tahun 2000 s/d 2002 maka yang berlaku adalah pasal-pasal yang telah ditetapkannya hasil amandemen Undang-Undang Dasar oleh Majelis Permusyawarata Rakyat Republik Indonesia sehingga pasal-pasal yang dialkukan perubahan tidak bisa menjadi sumber hokum lagi. Sebagai contoh lagi adalah Undang-Undang Nomor 10 Tahun 2004 Tentang Pembentukan Peraturan PerundangUndangan tidak berlaku lagi sejak ditetapkannnya Undang-Undang Nomor 12 Tahun 2011.

2. Lex specialis derogate legi peneralis (peraturan yang lebih khusus mengenyampingkan peraturan yang lebih umum);

Asas ini mengisyaratkan bahwa peraturan yang lebih khusus mengenyampingkan peraturan yang lebih umum, peraturan yang bersifat umum di Indonesia adalah peraturan yang terdapat di dalam Kitab Undang-Undang Hukum Pidana maupun Kitab Undang-Undang Hukum Perdata. Sebagai contoh dengan

\footnotetext{
${ }^{1}$ Dosen Fakultas Hukum Universitas Batanghari Jambi

${ }^{2}$ Dosen Fakultas Hukum STKIP YPM Bangko

${ }^{3}$ Student doctoral program ums Surakarta, Lecture Batik Islamic University of Surakarta
} 
berlakunya Undang-Undang Nomor 36 Tahun 2009 Tentang Kesehatan maka ketentuan pidana yang diterapkan adalah ketentuan yang terdapat di dalam undang-undang tersebut bukan didasarkan kepada KUHPidana. Contoh lain adalah batas usia dewasa untuk menurut Pasal 330 KUHPerdata adalah 21 tahun sedangkan menurut Undang-Undang Perkawinan, Undang-Undang Administrasi Kependudukan, Undang-Undang Perlindungan Anak, Undang-Undang Kesejahteraan Anak, Undang-Undang Ketenagakerjaan, Undang-Undang Pemasyarakatan, Undang-undang Pengadilan Anak, Undang-Undang HAM, Undang-Undang Kewarganegaraan, Undang-Undang Tindak Pidana Perdagangan Orang adalah 18 tahun, maka secara kasuistik penerapan aturannya adalah usia 18 tahun bukan usia yang diatur dalam KUHPerdata.

3. Lex superior derogate legi inferior (peraturan yang lebih tinggi mengenyapingkan hokum yang lebih rendah);

Berdasarkan Pasal 7 Undang-Undang Nomor 12 Tahun 2011 Tentang Pembentukan Peratuiran Perundang-undangan, urutan peraturan perundang-undangan di Indonesia adalah Undang-Undang Dasar 1945 (UUD), Ketetapan MPR (TAP MPR), Undang-Undang (UU), Peraturan Pemerintah (PP), Peraturan Presiden (Perpres), Peraturan Daerah Propinsi (Perda Propinsi), dan Peraturan Daerah Kota/Kabupaten (Perda Kota/Propinsi).

Hal ini berlaku secara hirarkhis dan sistematis dalam artian jika ada ketentuan hokum yang terdapat dalam UU yang tidak sesuai dengan UUD maka aturan tersebut dapat dikesampingkan, demikian pula jika dalam Peraturan Pemerintah (PP) yang tidak sejalan dengan Undang-Undang maka aturannya dapat dikesamping.

Beberapa asas hukum ini selayaknya dapat dijunjung tinggi dan dihormati dalam pembentukan peraturan perundang-undangan dan praktik hukum konkrit karena dalam kenyataannya asas-asas hukum ini masih dilanggar oleh penegak hokum dalam menangani suatu kasus hukum.

Menurut Nurfauzia, Pada tahap penyelesaian perjanjian dalam hal jual memiliki 3 tahap antara lain musyawarah mufakat, Pengadilan Negeri Jambi dan gugatan sita jaminan. ${ }^{4}$ Sedangkan dalam penyelesaian sengketa melalui arbitrase berlaku asas-asas yang bersifat khusus, diantaranya adalah:

1. Pengadilan Negeri tidak berwenang untuk mengadili sengketa para pihak yang telah terikat perjanjian arbitrase (Pasal 3)

2. Adanya suatu perjanjian arbitrase tertulis meniadakan hak para pihak untuk mengajukan penyelesaian sengketa atau beda pendapat yang termuat dalam perjanjian ke Pengadilan Negeri (Pasal 11 Ayat 1)

3. Putusan arbitrase bersifat final dan mempunyai kekuatan hukum tetap dan mengikat para pihak (Pasal 60)

Dalam ketentuan hukum yang terdapat dalam Undang-Undang Nomor 30 Tahun 1999 masih terdapat ketentuan yang bertentangan dengan asas hukum yang berlaku dalam arbitrase itu sendiri, bahkan asas hukum tersebut merupakan asas hokum yang sangat penting dalam arbitrase yaitu asas absolute authority dan final and binding decision, hal ini akan berdampak luas terhadap kepercayaan pelaku bisnis dalam menyelesaian sengketa dagang sebagai alternatif penyelesaian sengketa.

Berdasarkan pertimbangan tersebut maka akan dilakukan penelitian yuridis normatif terhadap beberapa asas yang dikangkangi dalam Undang-Undang Nomor 30 Tahun 1999 Tentang Arbitrase dan Alternatif Penyelesaian Sengketa (APS)

\section{METODE PENELITIAN}

Dalam penelitian ini penulis menggunakan tipe penelitian yuridis normatif yaitu penelitian yang difokuskan kepada norma-norma yang terdapat dalam suatu peraturan peundangan-undangan, sedangkan pendekatan yang digunakan adalah pendekatan perundang-undangan dan pendekatan konsep dengan cara mengungkapkan beberapa asas-asas hukum yang berkaitan dengan arbitrase, pembahasan dilakukan dengan cara deduktif untuk memperoleh kesimpulan yang bersifat kualitatif.

${ }^{4}$ Nurfauzia, Penyelesaian Wanprestasi pada Perjanjian Jual Belisarana Produksi Pertanian (Saprodi) antara CV Karya Tani dengan Toko Riska Tani, Jurnal Wajah Hukum, Volume 2 Nomor 2 (Oktober 2018), hal.16-162. 


\section{HASIL DAN PEMBAHASAN \\ Pengertian Asas Hukum}

Pengertian asas hukum menurut Kamus Besar Bahasa Indonesia adalah:

a. Dasar, alas, pedoman

b. Suatu kebenaran yang menjadi pokok atau tumpuan berfikir

c. Cita-cita yang menjadi dasar

Asas hukum adalah sesuatu hal yang sangat mendasar dalam hukum, dan menjadi pedoman baik dalam pembentukan hukum maupun praktik hukum, asas hukum mengangdung nilai kebenaran yang harus dijunjung tinggi sebagai suatu kebenaran yang hakiki dalam suatu kaedah hukum, atau asas hukum juga dapat dijadikan sebagai suatu hal yang ingin dicapai, diraih dalam kaitannya tentang tujuan hukum di suatu negara.

Asas hukum bersifat abstrak, maka asas hukum pada umumnya tidak dituangkan dalam peraturan atau pasal yang konkrit. Kalau peraturan hukum konkrit itu dapat secara langsung diterapkan kepada peristiwa yang konkrit, maka asas hukum karena bersifat abstrak tidak dapat diterapkan secara langsung kepada peristiwa konkrit, ${ }^{5}$ menurut beliau asas hukum dapat dibagi dua, yaitu asas hukum umum dan asas hukum khusus:

Asas hukum umum adalah asas hukum yang berhubungan dengan seluruh bidang hukum seperti asas lex posterior derogat legi priori, asas bahwa apa yang lahirnya tampak sebagai benar (sah), untuk sementara harus dipertahankan demikian sampai diputus lain oleh pengadilan,asas demi kepastian hukum, asas nebis in idem. Asas hukum khusus berfungsi dalam bidang yang lebih sempit seperti dalam bidang hukum perdata, hukum pidana dan sebagainya, yang sering merupakan penjabaran dari asas hukum umum, seperti pacta sunt servanda, asas konsensualisme, asas yang tercantum dalam pasal 1977 KUHPerdata, asas praduga tak bersalah. ${ }^{6}$

Menurut J.J. H. Brugging asas hukum adalah "kaidah yang memuat ukuran (kriteria) nilai,"7 yaitu nilai-nilai umum yang ingin diraih, asas hukum berfungsi sebagai meta-kaidah terhadap kaidah perilaku, karena menentukan interpretasi terhadap aturan hukum dan dengan itu wilayah penerapan aturan tersebut, tetapi asas hukum juga pedoman bagi perilaku, walaupun dengan cara yang kurang langsung jika dibandingkan dengan kaidah perilaku.

Dalam buku Dasar-Dasar Ilmu Hukum, Ishaq merangkum beberapa pendapat para ahli tentang pengertian asas hukum:

1. Pendapat Bellefroid: asas hukum adalah norma dasar yang dijabarkan dari hukum positif dan yang oleh ilmu hukum tidak dianggap berasal dari aturan yang lebih umum. Asas hukum umum itu merupakan pengedepanan hukum positif dalam suatu masyarakat

2. Pendapat van Eikema Hommes mengatakan bahwa asas hukum itu tidak boleh dianggap sebagai normanorma hukum yang konkrit, akan tetapi perlu dipandang sebagai dasar-dasar umum atau petunjukpetunjuk bagi hukum yang berlaku. Pembentukan hukum praktis perlu berorientasi pada asas-asas hukum tersebut. Dengan kata lain asas hukum ialah dasar-dasar petunjuk arah dalam pembentukan hukum positif

3. Pendapat van der Velden. Asas hukum adalah tipe putusan yang dapat digunakan sebagai tolok ukur untuk menilai situasi atau digunakan sebagai pedoman berperilaku. Asas hukum didasarkan atas nilai atau lebih yang menentukan siatuasi yang bernilai yang harus direalisasi

4. Menurut Scholten, bahwa asas hukum adalah kecenderungan yang disyaratkan oleh pandangan kesusilaan kita pada hukum, merupakan sifat-sifat umum dengan segala keterbatasannya sebagai pembawaan yang umum itu, tetapi yang tidak boleh tidak harus ada ${ }^{8}$

\footnotetext{
${ }^{5}$ Sudikno Mertokusumo, Penemuan Hukum, Liberty, Yogyakarta, 2009, hal.7.

${ }^{6}$ Ibid, hal. 10-11.

${ }^{7}$ J.J. H. Brugging, Op. Cit. hal. 123.

${ }^{8}$ Ishaq, Dasar-dasar Ilmu Hukum, Sinar Grafika, Jakarta, 2009, hal. 75-76.
} 
Dari beberapa pengertian dan pembatasan tentang asas hukum maka asas hukum mengandung unsurunsur:

1. Asas hukum merupakan hal yang sangat mendasar dalam hukum

2. Asas hukum bersifat abstrak sehingga tidak dapat diterapkan dalam peristiwa konkrit

3. Asas hukum menjadi pedoman dalam berperilaku dan menjadi pedoman dalam sistem dan pembentukan hukum

4. Asas hukum tidak boleh dianggap sebagai norma konkrit

Asas hukum pada dasarnya memiliki dua kedudukan dalam suatu sistem hukum yaitu:

1. Asas hukum bersifat abstrak dan tidak dituangkan dalam kaidah hukum akan tetapi asas hukum dijadikan pedoman bagi kaidah hukum dan dalam penemuan hukum, dalam konteks ini asas hukum tidak dapat diterapkan dalam peristiwa konkrit, seperti asas "setiap orang dianggap tahu akan undang-undang", "perlindungan terhadap pihak ketiga yang beritikad baik", "siapa yang mempunyai kepentingan hukum dapat mengajukan gugatan".

2. Asas hukum yang dituangkan dalam bentuk peraturan konkrit atau pasal-pasal dalam suatu peraturan perundang-undangan seperti Pasal 1320 KUHPerdata tentang asas konsensus, asas kecakapan, asas kausa yang halal, Pasal 1338 KUHPerdata tentang asas pacta sunt servanda dan good faith, Pasal 60 UndangUndang Nomor 30 tahun 1999 tentang asas putusan arbitrase bersifat final dan mempunyai kekuatan hukum dan mengikat para pihak (final and binding)

Dalam setiap asas hukum terlihat suatu cita-cita yang hendak diraih, suatu cita-cita, atau harapan, suatu ideal, asas hukum memberi dimensi etis kepada hukum. Asas hukum menjadi pedoman bagaimana seharusnya kaidah hukum yang akan diberlakukan, kaidah hukum harus disinkronkan dengan asas hukum agar cita-cita hukum dapat diraih, dengan demikian kaidah hukum harus menterjemahkan apa yang diinginkan oleh asas hukum.

Apakah asas hukum dapat berubah?, menurut Sudikno Mertokusumo "asas hukum pada umumnya bersifat dinamis, berkembang mengikuti kaidah hukumnya, sedangkan kaidah hukum akan berubah mengikuti perkembangan masyarakat, jadi terpengaruh waktu dan tempat: "historisch bestiment" . Walaupun pada umumnya asas hukum bersifat dinamis, menurut Scholten ada asas hukum yang bersifat universal yang berlaku kapan saja dan di mana saja, tidak terpengaruh waktu dan tempat. Ada lima asas hukum universal, yaitu asas kepribadian, asas persekutuan, asas kesamaan, asas kewibawaan, dan asas pemisahan antara baik dan buruk. Menurut peneliti asas dapat dibedakan menjadi 2 (dua) macam yaitu asas hukum permanen dan asas hukum dinamis. ${ }^{10}$

Dengan demikian asas hukum mempunyai kedudukan yang sangat penting dalam suatu sistem hukum karena asas hukum menjadi landasan bagi kaidah hukum dan menjadi pedoman dalam pembentukan hukum, dalam teori hukum asas hukum termasuk dalam lingkup filsafat hukum yang berada di atas, teori hukum dan dogmatik hukum, serta penerapan hukum sehingga asas hukum tidak dapat dikesampingkan, pembahasan tentang teori, hukum, kaidah hukum dan penerapan hukum tidak boleh mengenyampingkan asas hukum, jika ditinjau dari asas sebagai suatu cita-cita maka sulit hukum akan meraih apa yang diinginkan oleh hukum. Menurut peneliti asas hukum harus dapat dijangkau dan dapat diraih karena jika tidak demikian maka tujuan hukum tidak akan pernah tercapai dan hanya sebatas angan-angan saja, sinkronisasi antara asas hukum dengan dogmatik perlu dilakukan, dimungkinkan asas hukum dapat diubah karena dalam praktiknya tidak dilaksanakan demikian pula sebaliknya. Menurut J.J.H.Brugging asas hukum mengemban fungsi ganda yaitu "sebagai pondasi dari sistem hukum positif dan sebagai batu-uji kritis terhadap sistem hukum positif."11

Berikut dapat dilihat kedudukan asas hukum menurut Farid Ali dalam bukunya Studi Sistem Hukum Indonesia, beliau menyatakan bahwa:

${ }^{9}$ Sudikno Mertokusumo, Op. Cit., hal. 9.

${ }^{10}$ Asas hukum permanen adalah asas yang tidak berubah oleh waktu dan tempat adalah asas hukum yang bersifat universal yang memiliki sifat yang sangat global dan umum, biasanya tidak dicantumkan dalam pasal-pasal, sedangkan asas hukum yang bersifat dinamis yaitu asas yang dapat berubah menurut waktu dan tempat, menurut kaidah hukumnya, dalam konteks ini asas hukum yang dapat berubah adalah asas hukum yang bersifat khusus yang diterapkan dalam bidang-bidang tertentu, biasanya dapat dicantumkan dalam pasal-pasal.

${ }^{11}$ J.J.H.Brugging, Op. Ci.t, hal. 133. 
Keberlakuan suatu asas merupakan kepastian dan oleh karena itu ketika ia diberlakukan untuk memecahkan masalah, tidak ada suatu keraguan atas kebenarannya dan oleh karena itu ia dapat dijadikan pengawal di dalam memutuskan suatu masalah. Dalam hal penegakan hukum, para penegak hukum tidak perlu ragu melakukan tindakan, dalam memberikan suatu keputusan hukum. Dengan asas, apa yang kita lakukan memiliki jaminan atas kebenarannya.

Asas biasa disebut dengan prinsip. Ia lahir dari suatu kesepakatan atas kebenaran sesuatu hal hasil pengkajian ilmu pengetahuan. Ia berada di atas teori. Jika teori masih dapat dibantah, ditolak, maka asas tidak dapatditolak atau dibantah. Memang demikian kebenaran keberlakuannya, dan oleh karena ia lahir dari teori sedangkan teori adalah hasil pembuktian atau suatu hipotesis yang diajukan, dan hipotesisi merupakan anggapan dasar yang disusun atas kajian terhadap realitas yang terjadi, maka setiap ilmu pengetahuan memiliki asas. ${ }^{12}$

Asas hukum merupakan suatu kepastian sehingga tidak perlu ragu dalam melaksanakannya, dan asas hukum menjadi pengawal dalam penerapan suatu aturan, apakah aturan yang dituangkan atau yang dijalankan sesuai, sejalan dan tidak bertentangan dengan asas hukum. Asas hukum menduduki posisi tertinggi dalam suatu sistem hukum oleh karena itu pemberlakuannya memiliki kekuatan hukum, bahkan dalam suatu penerapan hukum jika tidak sesuai dengan asas hukum maka dapat dilakukan upaya pembatalan bahkan batal demi hukum. Sebagai contoh penerapan suatu ketentuan peraturan perundang-undangan yang sudah dinyatakan dicabut dan sudah diganti dengan aturan yang baru maka keputusan hukum tersebut tidak memiliki kekuatan hukum, tidak sah dan batal demi hukum, karena bertentangan dengan asas hukum: hukum kemudian meniadakan hukum sebelumnya (lex posterior derogate legi priori). ${ }^{13}$

Dengan demikian kedudukan asas hukum sangat strategis dalam suatu system hukum suatu negara karena kedudukannya di atas aturan itu sendiri bahkan jika suatu aturan hukum bertentangan dengan asas hukum maka aturan tersebut kedudukannya lemah, dalam penyelesaian sengketa melalui arbitrase dikenal beberapa asas yang berlaku baik berlaku secara umum dalam perjanjian maupun berlaku khusus dalam konteks arbitrase itu sendiri, jika dianalisis masih terdapat aturan hukum yang tertdapat dalam UndangUndang Nomor 30 Tahun 2009 Tentang Arbitrase dan Alternatif Penyelesaian Sengketa yang bertentangan dengan asas yang berlaku dalam arbitrase itu sendiri

\section{Asas-asas hukum dalam Arbitrase}

Dalam konteks penelitian ini peneliti mencermati adanya beberapa asas hukum yang dijadikan sebagai pedoman dengan aturan hukum yang tertuang dalam undang-Undang Nomor 30 Tahun 1999 Tentang Arbitrase dan Alternatif Penyelesaian Sengketa yaitu:

a. Asas kewenangan absolut arbitrase (absolute authority); Pengadilan Negeri tidak berwenang untuk mengadili sengketa para pihak yang telah terikat perjanjian arbitrase (Pasal 3)

b. Asas pacta suntservanda; Adanya suatu perjanjian arbitrase tertulis meniadakan hak para pihak untuk mengajukan penyelesaian sengketa atau beda pendapat yang termuat dalam perjanjian ke Pengadilan Negeri (Pasal 11 Ayat 1)

c. Asas Final and binding decision; Putusan arbitrase bersifat final dan mempunyai kekuatan hukum tetap dan mengikat para pihak (Pasal 60)

Asas pertama menegaskan bahwa Pengadilan Negeri tidak berwenang untuk mengadili sengketa para pihak yang telah terikat perjanjian arbitrase (Pasal 3) dan adanya suatu perjanjian arbitrase tertulis meniadakan para pihak untuk mengajukan penyelesaian sengketa atau beda pendapat yang termuat dalam perjanjian ke Pengadilan Negeri, merupakan konsekuensi dari asas Pacta Suntservanda yang mengisyaratkan bahwa setiap perjanjian yang dibuat secara sah menjadi undang-undang bagi para pihak yang terikat dalam perjanjian tersebut (Pasal 1338 KUHPerdata), walaupun demikian tetap saja terjadi kerancuan dalam undang-undang ini di mana dalam undang-undang ini diatur juga bahwa syarat untuk dapat dilaksanakannya putusan arbitrase terutama putusan arbitrase internasional harus didaftarkan di Pengadilan Negeri (Pasal 60), dengan demikian sebenarnya lembaga arbitrase tidak memiliki kewenangan absolut

\footnotetext{
${ }^{12}$ Farid Ali, et. al., Studi Sistem Hukum Indonesia, Refika Aditama, Bandung, 2012, hal. 120.

${ }^{13}$ Indonesia Legal Center Publishing, Kamus Hukum, Indonesia Legal Center Publishing, Jakarta, 2008, hal. 109.
} 
tertama dalam masalah eksekusi, berdasarkan fakta hukum di atas menunjukkan bahwa undang-undang ini telah menabrak asas dari arbitrase itu sendiri yaitu putusan arbitrase bersifat final dan binding.

Beberapa asas penting dalam arbitrase internasional dapat peneliti uraikan sebagai berikut:

1. Free consent; menurut Mariam Darus "kebebasan berkontak yang bertanggung jawab." ${ }^{14}$ Para pihak pada prinsipnya mempunyai kebebasan yang seluas-luasnya untuk membuat suatu perjanjian atau kontrak dengan pihak lain, hal ini merupakan hak dasar yang diberikan kepada semua orang untuk mengikatkan dirinya dalam suatu perjanjian, asas ini merupakan asas yang sangat umum dan mendasar dalam suatu perjanjian arbitrase karena para pihak diberi kebebasan untuk memilih hukum mana yang akan digunakan jika terjadi sengketa dalam hubungan bisnis dan forum apa yang dipilih untuk menyelesaikan sengketa mereka, dengan demikian pilihan hukum dan pilihan forum yang disepakati oleh para pihak harus bebas dari tekanan dan intervensi pihak lain. Konsekuensi logis prinsip kebebasan berkontrak dalam perjanjian arbitrase adalah para pihak memiliki hak-hak untuk:

a. Pilihan forum (choise of jurisdiction), para pihak menentukan sendiri pengadilan atau forum mana yang berwenang memeriksa sengketa yang terjadi/akan terjadi

b. Pilihan hukum (choise of law), para pihak dapat menentukan sendiri hukum mana yang berlaku dalam kontrak tersebut termasuk hukum yang yang akan digunakan jika terjadi sengketa

c. Pilihan domisili (choise of domicile), para pihak dapat menetukan sendiri domisili hukum dari para pihak yang terikat perjanjian arbitrase

2. Pacta sunt servanda; menurut Munir Fuadi "kontrak mengikat" secara hukum, ${ }^{15}$ Arbitrase merupakan bentuk perikatan yang timbul karena perjanjian yang dibuat para pihak, perjanjian yang dibuat secara sah menjadi hukum bagi para pihak, merupakan asas yang memiliki kedudukan terpenting dalam suatu arbitrase karena para pihak terikat dengan perjanjian arbitrase yang telah mereka sepakati baik mengenai pilihan hukumnya dan pilihan forum arbitrase, konsekuensi hukumnya para pihak selayaknya menghormati dan melaksanakan semua putusan arbitrase yang sah dan sesuai dengan prosedur forum arbitrase

3. Good faith; Harry Purwanto mengatakan bahwa "pelaksanaan janji-janji tersebut harus dilaksanakan dengan penuh kesadaran, rasa tanggung jawab dan memperhatikan kepentingan para pihak," ${ }^{16}$ Suatu perjanjian yang secara sah dibuat oleh para pihak, maka para pihak harus memiliki keinginan/itikad baik untuk menghormati dan melaksanakan segala sesuatu yang sudah disepakati, merupakan tanggung jawab moral para pihak untuk melaksanakan dengan sungguh-sungguh semua kesepakatan yang telah dibuat, tanpa adanya itikad baik dari para pihak maka tidak mungkin suatu perjanjian dapat dilaksanakan

4. Resiprositas; menurut Syafrudin Yudowibowo "ikatan hubungan timbal balik,"17 dalam masalah pengakuan dan pelaksanaan putusan arbitrase asing, suatu negara A yang telah mengakui dan melaksanakan putusan arbitrase dari B, maka pada kasus lain selayaknya B harus mengakui dan melaksanakan putusan arbitrase dari negara A, jika tidak demikian maka tidak akan tercipta hubungan yang harmonis bagi kedua negara karena negara A yang tidak mau mengakui dan melaksanakan putusan arbitrase negara B pada kasus lain akan ditolak pula oleh negara B, selayaknya tidak ada alasan untuk tidak mengakui dan melaksanakan putusan arbitrase dari negara lain sepanjang tidak bertentangan dengan hukum yang berlaku, menurut Huala Adolf prinsip resiprositas "mengisyaratkan bahwa para pihak dalam kontrak harus melaksanakan hak dan kewajibannya masing-masing secara timbal balik. Menurut prinsip inji, pelaksanaan kontrak harus memberi "keuntungan" timbal balik"18

5. Non-diskriminasi; menurut Iza Fadri "konsesi yang terbaik yang diberikan satu negara mitra dagang harus berlaku pula bagi semua negara lainnya." ${ }^{19}$ Asas non-diskriminasi dalam arbitrase dalam suatu

\footnotetext{
${ }^{14}$ Mariam Darus, Op. Cit., hal. 5.

${ }^{15}$ Munir Fuadi, Op. Cit., hal. 210.

${ }^{16}$ Harry Purwanto, Op. Cit., hal. 157.

${ }^{17}$ Syafrudin Yudowibowo, "Eksekusi Putusan Arbitrase Internasional di Indonesia (Sebuah Perspektif Atas UU Nomor 30 Tahun 1999)",Jurnal Yustisia Edisi Nomor 71, 2007, hal.53.

${ }^{18}$ Huala Adolf, Dasar-Dasar Hukum Kontrak Internasional, Refika Aditama, Bandung, 2008, hal. 27.

${ }^{19}$ Iza Fadri, Politik Hukum Pidana Ekonomi Indonesia: Kebijakan dalam Era Liberalisasi Perdagangan Dunia, PTIK
} Press, 2013, hal. 191. 
negara memegang fungsi yang sangat fital karena asas ini menjunjung tinggi keadilan dan persamaan perlakuan kepada para pihak, dalam suatu sengketa di mana para pihak (A dan B) sepakat untuk menyerahkan penyelesaian sengketanya kepada suatu forum arbitrase yang berada di negara A, maka negara A tidak boleh melakukan diskriminasi terhadap B sehingga akan tercipta kepercayaan dari negara lain terhadap arbitrase di negara A.

6. National treatment; menurut Iza Fadri "produk yang telah masuk secara sah ke dalam wilayah pabean dari suatu negara harus diperlakukan sama dengan produk yang berasal dari negara pengimpor sendiri," ${ }^{20}$ asas national treatment memiliki tujuan yang sama dengan asas non-diskriminasiyaitu untuk memberikan perlakuan yang sama kepada semua negara dalam memeroses suatu sengketa arbitrase.

7. Partij autonomy; menurut Bambang Sutiyoso "pada prinsipnya pihak-pihak yang terlibat dalam suatu kontrak diberikan kebebasan untuk menentukan hukum mana yang berlaku dan forum penyelesaian sengketa mana yang diberlakukan ketika di kemudia hari terjadi suatu sengketa." 21 Dalam perjanjian arbitrase para pihak diberi kebebasan yang seluas-luasnya untuk memilih arbiter dan menentukan prosedur arbitrase berdasarkan kesepakatan bersama, atas dasar itu arbiter harus melaksanakan prosedur yang telah disepakati karena berdasarkan UNCITRAL Model Law arbiter yang tidak melaksanakan prosedur penyelesaian sengketa yang telah disepakati mengakibatkan putusan arbitrase dapat diajukan pembatalan sebagai suatu konsekuensi hukum bagi arbiter untuk melaksanakan kesepakatan para pihak.

8. Most quickly of time; menurut Gatot Sumartono "lebih cepat karena putusan arbitrase bersifat final dan mengikat, hingga menghemat waktu, biaya dan tenaga." ${ }^{22}$ Asas ini merupakan salah satu asas yang sangat penting dalam arbitrase dan menjadi keunggulan dari arbitrase dalam menyelesaikan sengketa dibandingkan dengan penyelesaian sengketa melalui peradilan umum. Janji untuk menyelesaikan sengketa dengan lebih cepat merupakan salah satu faktor mengapa para pelaku bisnis lebih cenderung memilih arbitrase, hal ini terbukti dalam rule of the game suatu lembaga arbitrase telah ditentukan maksimal waktu dalam proses arbitrase, akan tetapi sangat disayangkan ternyata undang-undang masih memberikan upaya hukum pembatalan putusan arbitrase dan banding atas pembatalan putusan arbitrase sehingga asas ini telah dikebiri oleh pembuat undang-undang yang dapat menghilangkan jati diri arbitrase sebagai lembaga penyelesaian sengketa dengan cepat (most quickly of time), menurut peneliti asas ini memberikan pedoman bahwa proses arbitrase harus dapat menyelesaikan sengketa dengan cepat, hal ini menjadi tanggung jawab pembuat undang-undang untuk menghilangkan pasal-pasal penghambat dalam proses arbitrase

9. Ex aequo et bono; menurut Madjedi Hasan "apa yang adil dan wajar atau sesuai dengan rasa keadilan dan hati nurani. ${ }^{23}$ Dalam penyelesaian sengketa arbitrase ada permintaan khusus dari para pihak yaitu agar arbiter dapat mengambil keputusan berdasarkan kepatutan, keadilan dan hati nurani yaitu memohon agar arbiter dapat memutus sengketa dengan seadil-adilnya, keputusan yang dijatuhkan adalah patut dan harus didasarkan kepada rasa keadilan dari hati nurani, dalam hal ini berarti arbiter dapat mengenyampingkan norma positif yang berlaku. Walaupun demikian keputusan arbiter tetap memiliki kekuatan hukum yang sama bagi para pihak dan putusan arbiter merupakan putusan hukum, secara hukum keputusan arbiter harus dihormati dan dilaksanakan dengan penuh rasa tanggung jawab

10. Confidensial: menurut Mariam Darus pengertian confidensial adalah "kerahasiaan," 24 asas ini merupakan suatu asas yang khusus dalam proses arbitrase karena tidak dianut dalam proses hukum melalui peradilan umum, asas ini memiliki keunggulan karena proses persidangan bersifat sangat tertutup yang hanya dihadiri oleh para pihak yang mempunyai kepentingan dalam sengketa sehingga hal-hal yang bersifat rahasia tidak terbuka ke publik. Segi positif dari asas ini nama baik dan reputasi para pihak akan tetap terjaga dan terhindar dari konsumsi media yang cenderung menimbulkan kerugian bagi para pihak

${ }^{20}$ Ibid, hal. 192.

${ }^{21}$ Bambang Sutiyoso, “Akibat Pemilihan Forum Dalam Kontrak Yang Memuat Klausula Arbitrase”,Jurnal Mimbar Hukum. Volume 24 Nomor 1, 2012, hal. 160.

${ }^{22}$ Gatot Sumartono, Arbitrase dan Mediasi di Indonesia, Gramedia Pustaka Utama, Jakarta, 2006, hal. 13.

${ }^{23}$ Madjedi Hasan, "Ex Aequo Et Bono Decision", Indonesia Arbitration Quarterly Newsletter Volume 6 Nomor 4, 2014, hal. 22.

${ }^{24}$ Mariam Darus, Op. Cit, hal. 8. 
11. Final; putusan yang telah dijatuhkan oleh arbitrase adalah putusan terakhir dalam arti tidak ada upaya hukum lain yang dapat dilakukan oleh salah satu pihak. Asas ini sebenarnya merupakan asas yang sangat penting dalam penyelesaian sengketa melalui arbitrase karena sejalan dengan prinsip penyelesaian sengketa melalui arbitrase, akan tetapi asas ini menjadi tidak berfungsi karena tergilas oleh adanya aturan-aturan pembolehan dilakukannya upaya hukum lain seperti upaya pembatalan putusan arbitrase dan banding atas putusan arbitrase ke peradilan umum walaupun asas ini dinyatakan secara tegas dalam pasal akan tetapi kontradiktif dengan pasal lain yang memberi peluang untuk melakukan upaya hukum. Suleman Batubara menyatakan bahwa:

Sifat final yang demikian, sejalan dengan asas arbitrase yang menghendaki proses penyelesaian yang cepat dan sederhana. Sementara itu, maksud putusan yang bersifat binding, putusan tersebut sejak dijatuhkan langsung "mengikat" kepada para pihak. Dampak lanjut dari sifat binding menimbulkan akibat kekuatan eksekutorial. Apabila putusan tidak dilaksanakan secara sukarela oleh pihak yang dikalahkan, putusan dapat dijalankan pelaksanaannya secara paksa oleh badan kekuasaan resmi melalui peradilan. Memang harus demikian sifat dan kekuatan putusan Mahkamah Arbitrase, harus mengikat dan mempunyai kekuatan eksekutorial. Untuk apa ada putusan kalau tidak dapat dijalankan dengan paksa apabila pihak yang kalah enggan memenuhi secara sukarela ${ }^{25}$

12. Binding; menurut Jelli Nasseri "putusan dari suatu arbitrase internasional (asing) merupakan putusan yang mengikat dan mempunyai kekuatan eksekutorial terhadap para pihak yang terlibat dalam suatu sengketa," ${ }^{26}$ pada dasarnya sejak saat putusan arbitrase ditandatangani maka pada saat itu putusan telah memiliki kekuatan secara hukum dan tidak memerlukan syarat hukum lain agar putusan tersebut menjadi mengikat para pihak, untuk suatu putusan yang mengikat maka putusan tersebut harus diterima dengan itikad baik termasuk untuk melakukan eksekusi putusan secara sukarela.

13. Capability of party; menurut Subekti "orang yang membuat suatu perjanjian harus cakap menurut hukum,"27 para pihak yang membuat perjanjian arbitrase harus cakap bertindak secara hukum merupakan asas penting dalam arbitrase, syarat-syarat kecakapan diatur menurut aturan hukum yang berlaku, perjanjian yang tidak dibuat oleh pihak yang tidak memiliki kecakapan bertindak maka akan menjadi dasar dibatalkannya putusan arbitrase sebagaimana yang telah dijelaskan sebelumnya.

Oleh karena asas hukum ini bukan sebagai suatu norma yang konkrit maka dapat praktiknya sering diterjang dan dikesampingkan oleh pembentuk peraturan perundang-undangan sehingga undang-undang yang ditetapkan menabrak asas hukum itu sendiri, sehingga dengan kondisi demikian jika kembali kepada konsep asas hukum sebagai sesuatu yang sangat mendasar dan hal-hal yang menjadi tujuan hukum itu sendiri tidak akan tercapai, sehingga kepastian hukum dan keadilan sulit untuk dicapai dalam penyelesaian sengketa melalui arbitrase. Oleh karenanya perlu adanya pemikiran yang konstruksi dengan melakukan perubahan terhadap pasal-pasal yang terdapat dalam Undang-Undang Nomor 30 Tahun 1999 yang nyatanyata bertentangan dengan asas yang berlaku dalam penyelesaian sengketa melalui arbitrase sehingga pertimbangan moral (filosofis) dari dibentuknya undang-undang ini akan tercapai.

\section{SIMPULAN}

Arbitrase sebagai salah satu alternatif penyelesaian sengketa dibentuk berdasarkan Undang-Undang Nomor 30 Tahun 1999, sebagai lembaga penyelesaian sengketa, Arbitrase dibentuk didasarkan prinsip dan asas yang agung yaitu arbitrase memiliki kewenangan absolut dan putusan arbitrase bersifat final dan binding, akan tetapi ketentuan yang terdapat dalam undang-undang tersebut tidak sejalan bahkan bertentang dengan asas-asas hukum yang dianut oleh arbitrase itu sendiri. Jika hal ini dibiarkan maka akan mematikan kepercayaan pelaku bisnis dalam menyelesaian sengketa melalui arbitrase, oleh karena itu perlu dilakukan perubahan yang sangat fundamental terhadap undang-undang ini agar sejalan dengan moral (filosofis) dibentuknya lembaga arbitrase di Indonesia.

\footnotetext{
${ }^{25}$ Suleman Batubara dan Orinton Purba, Op. Cit., hal. 89.

${ }^{26}$ Jelly Nasseri, "Eksistensi Konvensi New York Dalam Pelaksanaan Putusan Arbitrase Internasional di Indonesia," Indonesia Arbitration Quaterly Newsletter Volume 7 Nomor 1, 2015, hal. 9.

${ }^{27}$ Subekti, Hukum perjanjian, Intermasa, Jakarta, hal. 17.
} 


\section{DAFTAR PUSTAKA}

Bambang Sutiyoso. 2012. "Akibat Pemilihan Forum Dalam Kontrak Yang Memuat Klausula Arbitrase”,Jurnal Mimbar Hukum. Volume 24 Nomor 1.

Farid Ali, et. al., 2012. Studi Sistem Hukum Indonesia, Refika Aditama, Bandung.

Gatot Sumartono. 2006.Arbitrase dan Mediasi di Indonesia, Gramedia Pustaka Utama, Jakarta.

Harry Purwanto. 2009. Keberadaan Asas Pacta Sunt Servanda Dalam Perjanjian Internasional. Jurnal Mimbar Hukum, Volume 21 Nomor 1

Huala Adolf. 2008.Dasar-Dasar Hukum Kontrak Internasional, Refika Aditama, Bandung.

Ishaq. 2009.Dasar-dasar Ilmu Hukum, Sinar Grafika, Jakarta.

Indonesia Legal Center Publishing. 2008.Kamus Hukum, Indonesia Legal Center Publishing, Jakarta.

Iza Fadri. 2013.Politik Hukum Pidana Ekonomi Indonesia: Kebijakan dalam Era Liberalisasi Perdagangan Dunia, PTIK Press.

Jelly Nasseri. 2015. "Eksistensi Konvensi New York Dalam Pelaksanaan Putusan Arbitrase Internasional di Indonesia," Indonesia Arbitration Quaterly Newsletter Volume 7 Nomor 1.

J.J. H. Brugging. 1999. Refleksi Tentang Hukum. Citra Aditya. Bandung.

Madjedi Hasan. 2014. "Ex Aequo Et Bono Decision”, Indonesia Arbitration Quarterly Newsletter Volume 6 Nomor 4.

Mariam Darus. 2003. Beberapa pemikiran mengenai penyelesaian sengketa di bidang ekonomi keuangan di luar pengadilan. bahan seminar dan lokakarya Pembangunan Hukum Nasional ke VIII.

Munir Fuadi. 2006. Arbitrase Nasional AlternatifPenyelesaian Sengketa Bisnis. Citra Aditya Bhakti. Bandung

Nurfauzia, Penyelesaian Wanprestasi pada Perjanjian Jual Belisarana Produksi Pertanian (Saprodi) antara CV Karya Tani dengan Toko Riska Tani, Jurnal Wajah Hukum, Volume 2 Nomor 2

Suleman Batubara dan Orinton Purba. 2013. Arbitrase Internasional: Penyelesaian Sengketa Investasi Asing melalui ICSID, UNCITRAL dan SIAC. Raih Asa Sukses. Depok.

Subekti, Hukum perjanjian, Intermasa, Jakarta.

Sudikno Mertokusumo. 2009.Penemuan Hukum,Liberty, Yogyakarta.

Syafrudin Yudowibowo. 2007. "Eksekusi Putusan Arbitrase Internasional di Indonesia (Sebuah Perspektif Atas UU Nomor 30 Tahun 1999)”,Jurnal Yustisia Edisi Nomor 71.

\section{Peraturan Perundang-undangan}

Republik Indonesia. Undang-Undang Nomor 30 Tahun 1999 Tentang Arbitrase dan Alternatif Penyelesaian Sengketa (Lembaran Negara Republik Indonesia Tahun 1999 Nomor 138) 